\title{
Water-Stress Influences on Three New Promising HLB-Tolerant Citrus Rootstocks
}

\author{
Lidia Aparicio-Durán ${ }^{1, * \mathbb{D}}$, Frederick G. Gmitter Jr. ${ }^{2} \mathbb{D}$, Juan M. Arjona-López ${ }^{1} \mathbb{D}$, Rocío Calero-Velázquez ${ }^{1} \mathbb{D}$, \\ Áurea Hervalejo ${ }^{1}$ (D) and Francisco J. Arenas-Arenas ${ }^{1}$ (D) \\ 1 "Las Torres" Center, Department of Agri-Food Engineering and Technology, Andalusian Institute of \\ Agricultural and Fisheries Research and Training (IFAPA), Ctra. Sevilla-Cazalla de la Sierra km. 12.2, \\ 41200 Alcalá del Río, Spain; juanm.arjona@juntadeandalucia.es (J.M.A.-L.); \\ rocio.calero@juntadeandalucia.es (R.C.-V.); aurea.hervalejo@juntadeandalucia.es (Á.H.); \\ fjose.arenas@juntadeandalucia.es (F.J.A.-A.) \\ 2 Citrus Research and Education Center, Department of Horticultural Sciences, IFAS, University of Florida, \\ Lake Alfred, FL 33850, USA; fgmitter@ufl.edu \\ * Correspondence: Lidia.aparicio@juntadeandalucia.es
}

check for updates

Citation: Aparicio-Durán, L.; Gmitter Jr., F.G.; Arjona-López, J.M.; Calero-Velázquez, R.; Hervalejo, Á.; Arenas-Arenas, F.J. Water-Stress Influences on Three New Promising HLB-Tolerant Citrus Rootstocks. Horticulturae 2021, 7, 336. https:// doi.org/10.3390/horticulturae7100336

Academic Editor: María José Rubio-Cabetas

Received: 29 July 2021

Accepted: 17 September 2021

Published: 24 September 2021

Publisher's Note: MDPI stays neutral with regard to jurisdictional claims in published maps and institutional affiliations.

Copyright: (c) 2021 by the authors. Licensee MDPI, Basel, Switzerland. This article is an open access article distributed under the terms and conditions of the Creative Commons Attribution (CC BY) license (https:/ / creativecommons.org/licenses/by/ $4.0 /)$.

\begin{abstract}
Drought and flooding conditions are increasingly common abiotic factors that affect citrus crops in both the Mediterranean Basin and Florida. Furthermore, emerging diseases, such as Huanglongbing (HLB), are a potential risk for these crops in those producing areas. This study aimed to evaluate the behavior under water-stress treatments of three new citrus rootstocks (UFR-6, B11R5T60, and $2247 \times 6070-02-2$ ) with reported tolerance of HLB, comparing them with a common commercial citrus rootstock (Carrizo citrange). Four water conditions were established: Control, Medium Water Stress (MWS), Drought, and Flooding. Chlorophyll index (SPAD), growth in height, relative growth rate, biomass (fresh and dry weight) and plant water status were evaluated. Citru rootstock response were different for each genotype; Carrizo citrange was negatively affected by all water treatments in the chlorophyll index (SPAD) and biomass production. By contrast, UFR- 6 showed a positive response in SPAD and growth under MWS and Drought, B11R5T60 displayed similar behavior to Control under all water stresses, and the response of 2247 x 6070-02-2 under MWS treatment was adequate but was not under Drought or Flooding conditions. Our study describes the behavior of these promising new citrus rootstocks against water stress; B11R5T60 exhibiting the best performance. These results can be useful for the citrus industry to address water-stress problems in these crops.
\end{abstract}

Keywords: drought; flooding; HLB; stomatal conductance; water status

\section{Introduction}

Citrus (Rutaceae family) is one the most financially important crops in the Mediterranean Basin and Florida (USA) [1]. Summer seasons with high temperatures lead to water restrictions and drought periods in the Mediterranean Basin, which is a semiarid region [2]. Furthermore, this region is suffering from a rise in soil desertification $[3,4]$. On the other hand, spring and fall seasons can generate dry periods in Florida. Flooding or waterlogging are common in both areas due to torrential rains and poor soil drainage and/or high clay content [5,6]. Moreover, climate change is increasing drought and flooding periods in the Mediterranean Basin's agro-systems [7,8].

Drought stress is one of the major abiotic factors limiting agriculture production, through restricting water availability for irrigation [9]. Citrus trees are quite sensitive to water deficiency, and various physiological alterations have been reported due to water restrictions [10]. One effect of early drought is stomatal closure, which diminishes stomatal conductance $\left(g_{s}\right)$ in order to reduce plant water loss $[11,12]$. Drought conditions reduce the capacity of photosynthesis and transpiration $[13,14]$. When this adverse situation persists over time, citrus plants decrease their growth, fruit production, and juice quality $[15,16]$. 
Flooding likewise has a negative impact on citrus trees, because they are described as sensitive [17] and result in economic losses [18] under this unfavorable environment. Flooding stress causes soil oxygen deprivation, which generates alterations in plant growth, development, and biomass [19]. Additionally, this disorder reduces leaf development and chlorophyll content, which leads to premature senescence abscission of leaves and a high incidence of shoot dieback $[14,20]$. Roots are markedly affected by flooding due to a hypoxic situation, generating reactive oxygen species and a mobilization of carbohydrates [21,22]. As in drought stress, flooding produces physiological changes in stomatal conductance, net carbon dioxide $\left(\mathrm{CO}_{2}\right)$ assimilation, and photosynthesis [23]. In addition, waterlogging situations result in a reduction in citrus fruit yield and quality [24].

Currently, the Mediterranean Basin's citrus orchards are under an emerging risk of Huanglongbing (HLB, or citrus greening disease). HLB is considered the most devastating citrus disease (Bové 2006), and it has caused significant financial and production losses in Florida since it was first reported in 2005 [25]. The presumed causal agent of HLB is Candidatus Liberibacter asiaticus ( $\mathrm{Ca}$ Las), a Gram-negative proteobacteria. This pathogen dramatically alters plant physiology, producing numerous symptoms, including leaf chlorosis and characteristic asymmetrical blotchy mottling, and reductions in fruit production and quality, and it ultimately leads to tree decline and even death a few years after initial infection [26-29]. CaLas is spread by the Asian citrus psyllid (ACP) vector, Diaphorina citri Kuwayama. Another species, Candidatus Liberibacter africanus (CaLaf), causes African greening (a less-aggressive but equally devastating citrus disease), and is vectored by another psyllid, Trioza erytreae Del Guercio. While neither of these species have yet been detected in Mediterranean Basin countries [30], T. erytreae has been found affecting citrus plants in Iberian mainland [31,32].

This threatening situation demands efforts now to find solutions for the new citriculture challenges ahead, as well as to avoid the damage that may arise from abiotic and biotic disorders, such as water stress and new devastating diseases like HLB. The appropriate use of citrus rootstock selection for limiting conditions in each region is both a sustainable method and a potential solution for abiotic and biotic problems. While citrus trees are sensitive to water stress, they can react with different molecular, anatomical, and biochemical signals for adapting to these adverse conditions [19]. As a permanent crop, citrus orchards frequently cover extensive monoculture areas, in which farmers grow them in a system with only one rootstock. In this sense, Carrizo citrange is the most common citrus rootstock used in Spain (approximately 61\% of citrus orchards) [33]. This rootstock has some degree of tolerance to flooding and drought conditions; however, its HLB tolerance is low [34-36]. Against this background, different citrus rootstock breeding programs, such as the University of Florida Citrus Education and Research Center (CREC), are working to obtain new citrus rootstocks with improved tolerance to abiotic and biotic limiting factors. Evaluation of HLB-tolerant rootstocks for characteristics that are critical in other important citrus-producing regions outside of Florida, such as the Mediterranean Basin, prior to the incursion of this disease, is imperative. Thus, three new, promising, and HLB-tolerant citrus rootstocks (UFR-6 [37] B11R5T60, and 2247 × 6070-02-2 [personal communication]) were selected for evaluation of their performance against drought and flooding stress, in comparison with the most commonly used commercial citrus rootstock in Spain, Carrizo citrange.

\section{Materials and Methods}

\subsection{Plant Material and Experimental Conditions}

Three new rootstocks from the CREC breeding program were assayed in this work with the reference and most commonly used citrus rootstock in Mediterranean citriculture, Carrizo citrange (sweet orange, Citrus sinensis L. Osb. X Trifoliate orange, Poncirus trifoliata L. Raf.). These new citrus rootstocks obtained by the University of Florida were: UFR-6 ('Changsha' mandarin (C. reticulata Blanco + Trifoliate orange 50-7)), which reported intermediate HLB incidence under field conditions, conferring high fruit yield and juice quality [37]; and B11R5T60 (P. trifoliata cv. Flying Dragon) x Ridge Pineapple sweet orange) 
and 2247 x 6070-02-2 (Nova + HBP x Sour orange + Flying Dragon), both of which are recently obtained citrus rootstocks with a tolerant response to HLB disease [personal communication]. Carrizo and B11R5T60 are diploid hybrids, but the others are tetraploid. All six-month-old citrus plants were obtained from and provided by Agromillora Group Nursery (Subirats, Barcelona, Spain) from in vitro culture.

The experiment was carried out with a total of 140 citrus plants in July 2020 under greenhouse conditions. The greenhouse is located in the "Las Torres" Center of the Andalusian Institute of Agricultural and Fisheries Research and Training (IFAPA), in Alcalá del Río, Seville, Spain $\left(37^{\circ} 30^{\prime} 43.3^{\prime \prime} \mathrm{N} ; 5^{\circ} 57^{\prime} 47.4^{\prime \prime} \mathrm{W}\right)$. Each citrus plant was transferred to 1.6 L pots with peat moss substrate. Next, all plants were acclimated for 10 days in the greenhouse, where they were irrigated three times a week with water equivalent to $100 \%$ of evapotranspiration.

\subsection{Water-Stress Treatments and Experimental Design}

Following the acclimation period, three plants of each rootstock were selected and harvested, after which their dry and fresh weights of roots, stems, and leaves were recorded. These three plants were used as controls for the initial status of each citrus rootstock, as well as to calculate the relative growth rate. Four different water-stress treatments were applied to the remaining plants (128) of all citrus rootstocks, using eight plants per treatment and rootstock $(n=8)$. Crop evapotranspiration was calculated to apply accurate water depending on temperature. Thus, Control plants were watered at $100 \%$ of crop evapotranspiration; Medium Water Stress (MWS) plants were watered at 50\% of crop evapotranspiration; Drought plants had complete water restrictions (plants were not watered in any of the experiments); and Flooding plants were in waterlogged conditions (plants were watered under saturated conditions, placing the plant pots in planter boxes, maintaining plenty of water throughout the experiment). The experiment was conducted under a factorial design with four repetitions (block) for 30 days (D30) using each plant as the experimental unit.

\subsection{Chlorophyll Index (SPAD) Evaluation}

The leaf chlorophyll index was measured for a total of eight plants using a SPAD chlorophyll meter (Minolta Co., Osaka, Japan). SPAD was measured on two expanded leaves per plant, every 10 days (i.e., D1, D10, D20, and D30).

\subsection{Plant Growth Evaluation}

The plant height of eight plants per rootstock and water-stress treatment was measured using a measuring tape every 10 days (D10, D20, and D30) from the beginning of the experiment (D1). The relative growth rate (RGR) was calculated using the increment of plant dry weight per unit (DW) per unit of time $(t)\left(\right.$ days $\left.^{-1}\right)$ [38], with the following equation:

$$
\operatorname{RGR}(\text { day }-1)=\frac{\operatorname{lnDWf}-\operatorname{lnDWi}}{\mathrm{tf}-\mathrm{ti}}
$$

where DWf is the dry weight at the end of the assay, and DWi is the initial dry weight divided by the difference between the final time (tf) and initial time (ti).

\subsection{Biomass}

At the end of the experiment (D30), all plants (eight plants per treatment and citrus rootstock) were cut and separated in three parts: roots (R), stems (S), and leaves (L). Fresh plant samples were weighed on a digital scale (COBOS Precision, CB-3000C, L'Hospitalet de Llobregat, Barcelona, Spain). The different plant samples were placed in a labeled paper envelope and then dried in an oven at $60^{\circ} \mathrm{C}$ for $48 \mathrm{~h}$ and weighed again to record dry weight. Percentage of biomass reduction (PBR, \%) was calculated for dry weight 
and fresh weight in each plant section for each sample and corrected with the Control treatment values, as adapted from Vincent's equation [39]:

$$
\operatorname{PBR}(\%)=\frac{(\mathrm{CW}-\mathrm{TW})}{\mathrm{CW}} \times 100
$$

where CW is the weight (g) of control treatment plants (no water added) averaged from eight replicates from dry weight (DW) and/or fresh weight (FW) and each section plant; and TW is the weight (g) of treated plants in each water-stress condition (MWS, Drought, and Flooding) from dry weight (DW) and/or fresh weight (FW) per sample replicate and section plant.

\subsection{Plant Water Status}

\subsubsection{Leaf Water Potential}

At the end of the experiment (D30), leaf water potential (LWP) was measured using a Pump-Up Scholander chamber (PMS Instrument Company, Albany, OR, USA) [40]. Two leaves per plant in a total of four plants per rootstock and treatment.

\subsubsection{Stomatal Conductance}

In the same experiment stage (D30) described above, stomatal conductance $\left(\mathrm{g}_{\mathrm{s}}\right)$ was recorded in duplicate per plant, for a total of four plants per citrus rootstock, using an SC-1 Leaf Porometer (Decagon Devices, Pullman, WA, USA) [41].

\subsubsection{Relative Water Content}

Relative water content (RWC) was estimated at the end of the experiment. Two mature and totally expended leaves per plant were selected, using a total of four plants per rootstock and treatment in this process. Thus, two discs per selective leaf of $1 \mathrm{~cm}$ in diameter were taken. All four discs obtained per plant were weighed using an AJ100 digital scale (METTLER TOLEDO, Columbus, OH, USA), then each group of four discs was covered with distilled water for $4 \mathrm{~h}$ at room temperature and weighed again. After this process, each group of discs was placed in a labeled paper envelope, dried for $24 \mathrm{~h}$ at $80^{\circ} \mathrm{C}$, and weighed. The RWC was calculated according to Morgan et al. [42] with the following equation:

$$
\operatorname{RWC}(\%)=\frac{(\mathrm{W}-\mathrm{DW})}{(\mathrm{TW}-\mathrm{DW})}
$$

where: $\mathrm{W}$ is the fresh weight of the four discs in each citrus rootstock and treatment, $\mathrm{TW}=$ discs turgent weight (after $4 \mathrm{~h}$ in distilled water), and DW is the dry weight discs.

\subsubsection{Electrolyte Leakage}

Electrolyte leakage (EL, \%) was calculated by cell membrane stability (CMS, \%). Two leaf discs ( $1 \mathrm{~cm}$ in diameter) were cut from one leaf, to which end two leaves per plant were selected per rootstock and treatment at the end of the experiment. Next, each group of four discs per plant was cleaned with distilled water twice, covered with $10 \mathrm{~mL}$ of distilled water in a $50 \mathrm{~mL}$ test tube, and incubated for $24 \mathrm{~h}$ at room temperature in darkness. After the incubation period, conductance was measured for both control plants and treated plants using a conductivity meter (METTLER TOLEDO, Columbus, OH, USA). Next, all samples were autoclaved at $121^{\circ} \mathrm{C}$ for $15 \mathrm{~min}$, and conductivity was measured when the samples acquired room temperature. New conductance of control plants and stressed plants was obtained by:

$$
\begin{gathered}
\text { CMS }(\%)=\frac{1-\frac{\mathrm{S} 1}{\mathrm{C} 1}}{1-\frac{\mathrm{S} 2}{\mathrm{C} 2}} \\
\mathrm{EL}(\%)=100-\mathrm{CMS} \%
\end{gathered}
$$


where $\mathrm{C} 1$ and $\mathrm{C} 2$ are the average of four replicated and stressed control plants, and S1 and S2 were measured for each water-stress treatment (MWS, Drought, and Flooding). EL was calculated at the beginning (D1) and at the end (D30) of the experiment.

\subsection{Data Analysis}

All data obtained were subjected to analysis of variance (ANOVA) using STATISTICA 10 software (StatSoft, Palo Alto, CA, USA). Means separation were obtained using Fisher's test $(p<0.05)$. Normality and homogeneity assumptions were tested before ANOVA, using the Kolmogorov-Smirnov and Cochran's test, respectively.

\section{Results}

\subsection{Chlorophyll Index (SPAD)}

Chlorophyll index values were different for each rootstock throughout the time period of the experiment. SPAD values in Carrizo citrange increased from the beginning until day 20; SPAD values were then reduced for all water treatments on the last evaluation day, except for the Control treatment. For UFR-6, SPAD values showed a similar behavior for all water treatments; these values increased gradually over time until day 30. B11R5T60 displayed a different response in SPAD values among the treatments, Control, Drought, and Flooding increased their SPAD response at the end of the experiment when comparing each of these treatments with the first day; by contrast, MWS showed a SPAD reduction in the last day compared with day 20. Lastly, 2247 x 6070-02-2 showed similar trends in Control, MWS, and Flooding treatments, which increased SPAD values throughout the experiment compared with the first day; however, the Drought treatment maintained SPAD responses that were similar to the other treatments until day 20, but SPAD values were lower on the last day (Figure 1).

\section{o Control $\equiv$ MWS $\star$ Drought $\nabla$ Flooding}
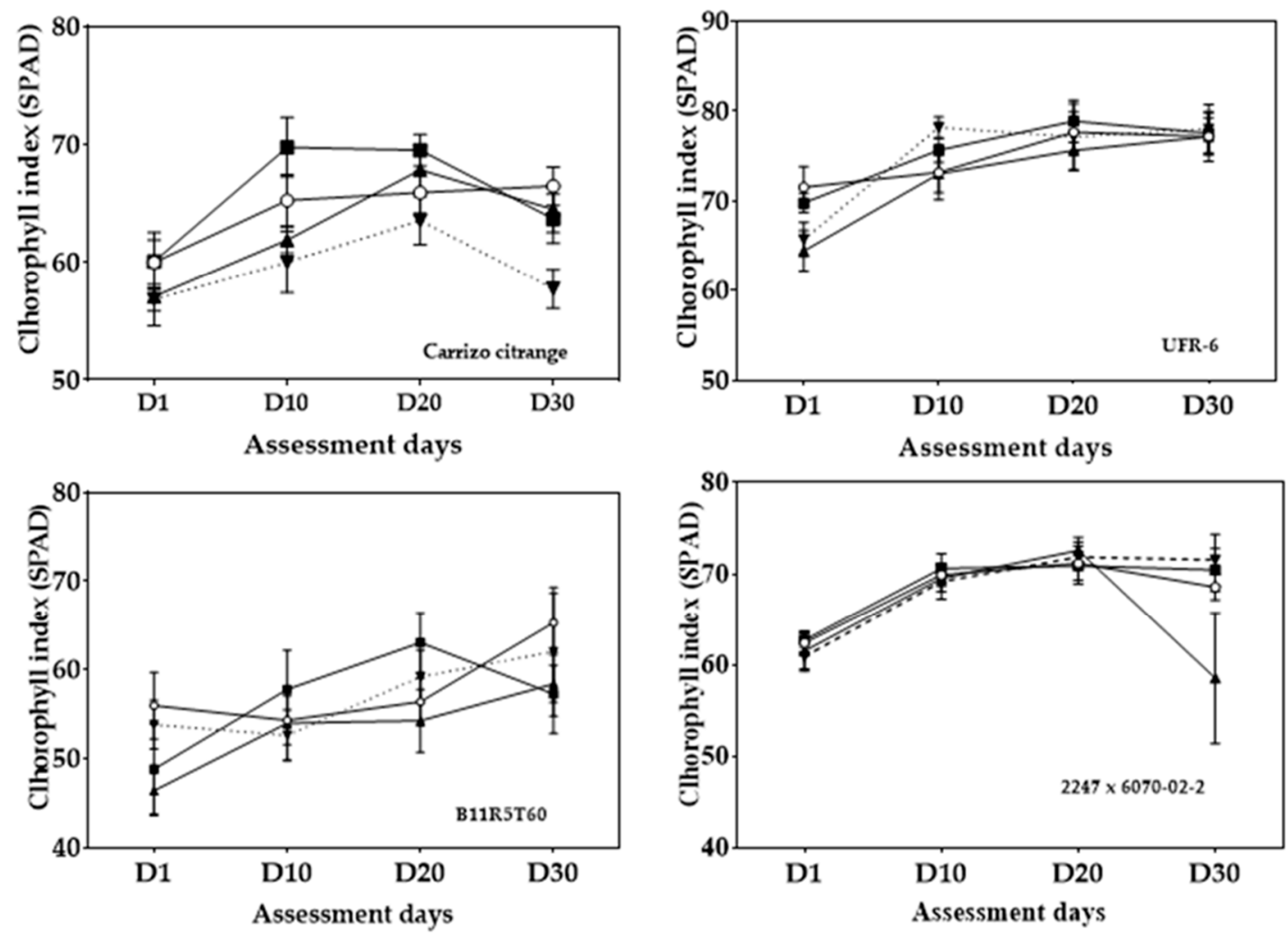

Figure 1. Time course for mean chlorophyll index (SPAD) values \pm standard error (SE) with four water treatments (Control, MWS, Drought, and Flooding) on four citrus rootstocks (Carrizo citrange, UFR-6, B11R5T60, and 2247 x 6070-02-2) during 30 days of assessment. MWS: Medium Water Stress. 


\subsection{Plant Growth}

For Carrizo citrange, plants from the Control treatment displayed the highest values of height during the entire assessment period compared with Flooding, MWS, and Drought, which showed a similar trend in plant growth among them. In the case of UFR-6, plants from the MWS and Control treatments displayed similar growth in height, with the highest values in the two last assessment days under MWS conditions; however, Flooding and Drought treatments showed the lowest values of height for assessment days 20 and 30. For the rootstock B11R5T60, treatments of Control and MWS displayed similar trend, being the highest values of height under Control conditions throughout all the assessment period; on the contrary, the lowest values of growth were achieved with the Flooding treatment from the assessment on day 10. Lastly, $2247 \times 6070-02-2$ displayed a similar growth trend between the Control and MWS treatments, and the highest values of height were achieved under MWS conditions during all the assessment periods; nevertheless, the lowest values of growth were achieved under Flooding conditions for the entire assessment period (Figure 2).

\section{o Control $=$ MWS $\star$ Drought $\nabla$ Flooding}
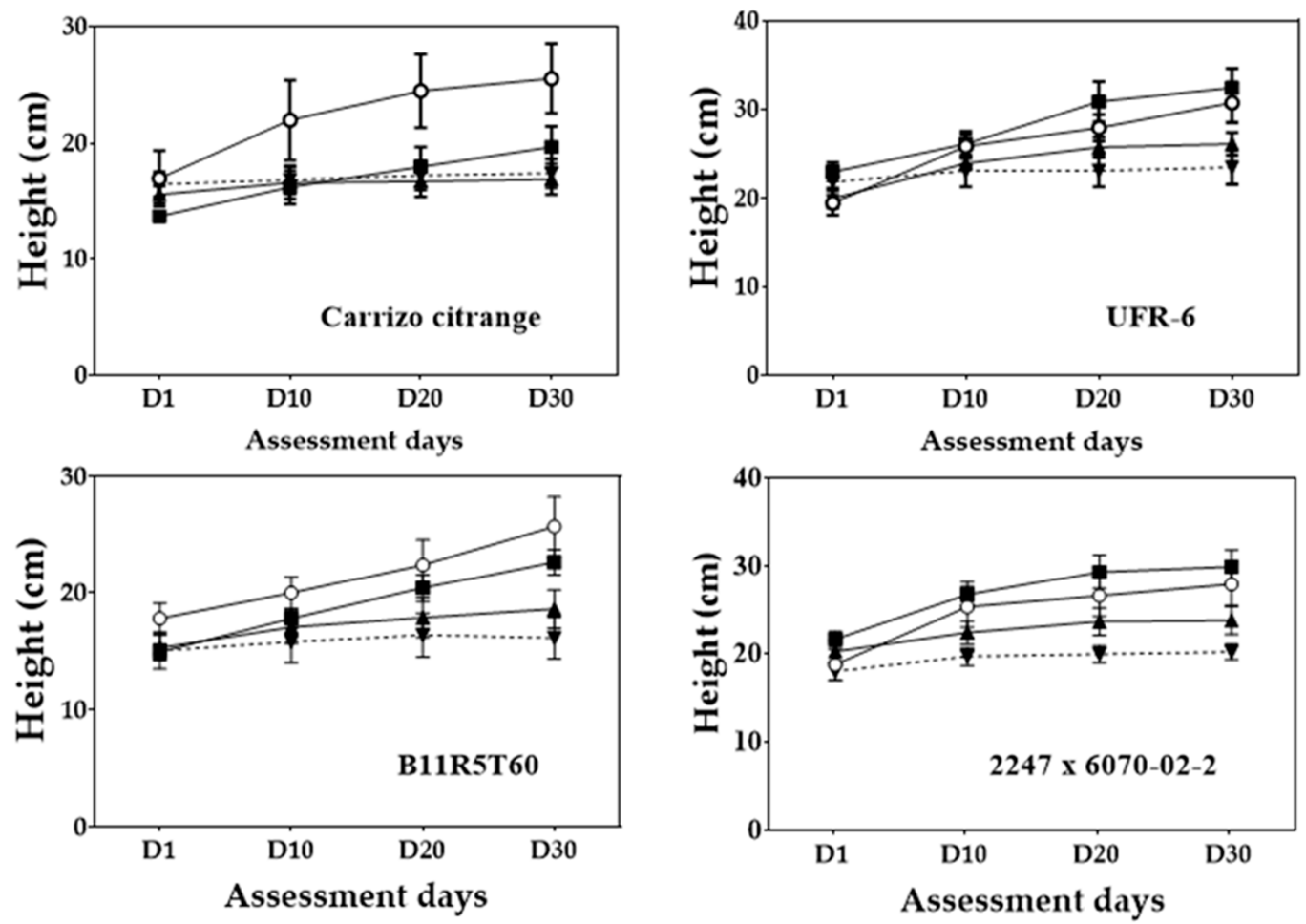

Figure 2. Time course for the mean height $(\mathrm{cm})$ values \pm standard error (SE) under four water treatments (Control, MWS, Drought, and Flooding) on four citrus rootstocks (Carrizo citrange, UFR-6, B11R5T60, and 2247 x 6070-02-2) over 11 weeks of evaluation. MWS: Medium Water Stress.

RGR response significantly decreased after application of water-stress treatments compared with the Control treatment for all citrus rootstocks assayed, except for B11R5T60. Carrizo citrange displayed the highest RGR in the Control treatment $\left(37.18\right.$ day $\left.^{-1}\right)$; RGR values decreased in all water-stress conditions, and the lowest significant value was achieved with the Flooding treatment $\left(22.89\right.$ day $\left.^{-1}\right)$. UFR-6 showed a decreasing trend among the treatments; the Flooding treatment reported the lowest RGR value $\left(25.01\right.$ day $\left.^{-1}\right)$, with significant differences compared to the highest RGR value, for the Control treatment $\left(42.22\right.$ day $\left.^{-1}\right)$. B11R5T60 did not show statistical differences among the treatments; however, the highest and lowest RGR values were achieved with the Control $\left(19.05 \mathrm{day}^{-1}\right)$ and Flooding treatments $\left(8.93\right.$ day $\left.^{-1}\right)$, respectively. Finally, 2247 x 6070-02-2 did not display sig- 
nificant differences between the Control $\left(50.26 \mathrm{day}^{-1}\right)$ and MWS conditions $\left(52.50 \mathrm{day}^{-1}\right)$, but the reduction in RGR for Drought $\left(39.89\right.$ day $\left.^{-1}\right)$ and Flooding $\left(37.71\right.$ day $\left.^{-1}\right)$ conditions was significantly different compared with the Control conditions (Figure 3).

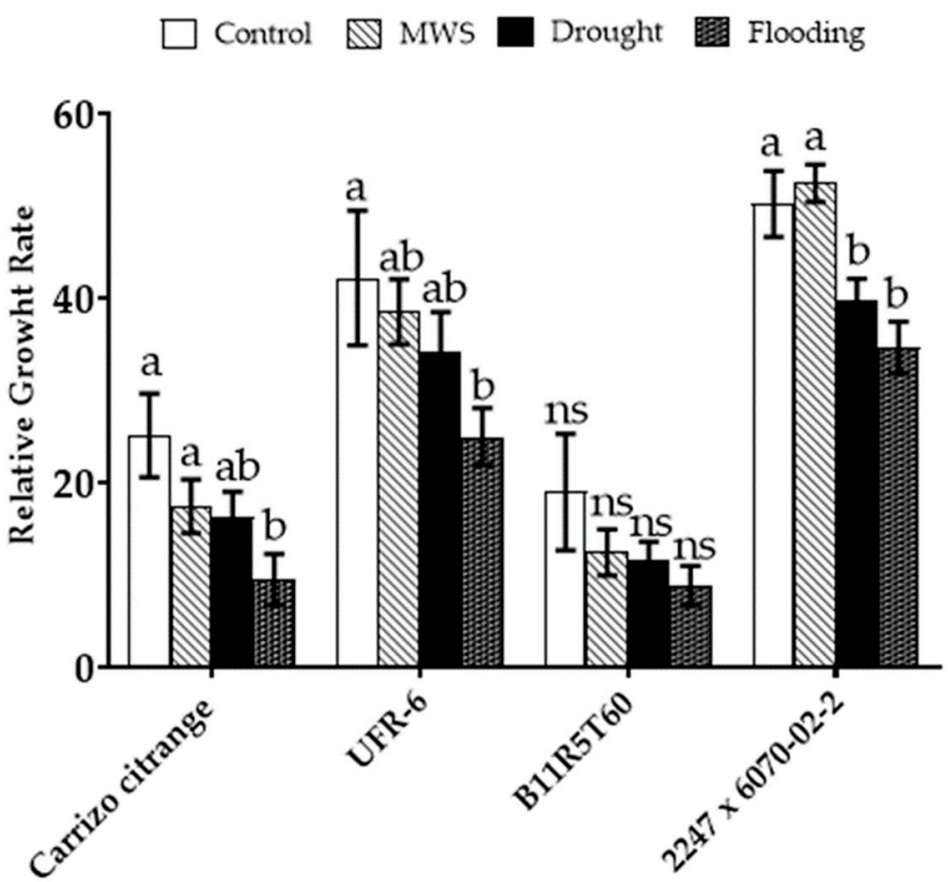

Citrus rootstocks

Figure 3. Relative growth rate (RGR; day ${ }^{-1}$ ) after 30 days (D30) under four water treatments (Control, MWS, Drought, and Flooding) and with four citrus rootstocks assayed (Carrizo citrange, UFR-6, B11R5T60, and 2247 x 6070-02-2). Values in columns with different letters indicate statistical differences among treatments for each rootstock by Fisher's test $(p<0.05)$. MWS: Medium Water Stress; ns: not significant.

\subsection{Biomass}

Percentage of biomass reduction was analyzed in fresh weight (FW) and dry weight (DW) conditions for each citrus rootstock and treatment. FW results showed a different behavior under different conditions. In the MWS treatment, Carrizo citrange showed the highest significant PBR in all analyzed plant tissue sections (roots, stems, and leaves) compared with the other citrus rootstocks per plant section. On the contrary, UFR-6 displayed the lowest significant PBR in all plant sections. For the Drought treatment, 2247 x 6070-02-2 reported the highest PBR reduction in roots and leaves, whereas Carrizo citrange did so in stems, compared with the other citrus rootstocks. Otherwise, B11R5T60 reported the lowest PBR in all plant sections analyzed. As to the Flooding treatment, the highest significant PBR was observed for B11R5T60 in stems and leaves, and $2247 \times 6070-02-2$ in roots. The lowest significant PBR was accomplished with UFR-6 in roots and stems, and with $2247 \times 6070-02-2$ in leaves (Table 1).

DW results revealed different courses of development depending on citrus rootstock and conditions. For the MWS treatment, B11R5T60, Carrizo citrange, and UFR-6 showed the highest PBR for roots, stems, and leaves, respectively, with statistical differences compared with the lowest values obtained. These lowest responses of PBR were achieved with UFR-6 in roots, and with $2247 \times 6070-02-2$ in stems and leaves. In the Drought treatment, $2247 \times 6070-02-2$, Carrizo citrange, and UFR-6 reported the highest significant PBR in roots, stems, and leaves, respectively. The lowest PBR rate was reached by B11R5T60 for roots, and by $2247 \times 6070-02-2$ for stems and leaves. Lastly, with the Flooding treatment, $2247 \times 6070-02-2$, Carrizo citrange, and UFR-6 displayed the highest significant PBR in roots, stems, and leaves, respectively. The lowest PBR was achieved with B11R55T60, UFR-6, 
and $2247 \times 6070-02-2$ in roots, stems, and leaves, respectively, with statistical differences compared with the highest rates (Table 1).

Table 1. Mean percentage of biomass reduction (PBR; \%) \pm standard error (SE) in roots (R), stems (S), and leaves (L) under fresh weight (FW) and dry weight (DW) conditions, after 30 days of water treatments (MWS, Drought, and Flooding) and with the four citrus rootstocks assayed (Carrizo citrange, UFR-6, B11R5T60, and 2247 x 6070-02-2).

\begin{tabular}{|c|c|c|c|c|c|c|c|}
\hline \multirow{2}{*}{$\begin{array}{c}\text { Water } \\
\text { Treatments }\end{array}$} & \multirow{2}{*}{ Rootstock } & \multicolumn{3}{|c|}{ FW } & \multicolumn{3}{|c|}{ DW } \\
\hline & & $\mathbf{R} \pm \mathbf{S E}$ & $\mathbf{S} \pm \mathbf{S E}$ & $\mathbf{L} \pm \mathbf{S E}$ & $\mathbf{R} \pm \mathbf{S E}$ & $\mathbf{S} \pm \mathbf{S E}$ & $\mathbf{L} \pm \mathbf{S E}$ \\
\hline \multirow{4}{*}{ MWS } & Carrizo citrange & $33.35 \pm 8.86 a$ & $32.92 \pm 6.44 \mathrm{a}$ & $33.17 \pm 8.77 \mathrm{a}$ & $14.03 \pm 5.21 \mathrm{ab}$ & $30.12 \pm 7.02 \mathrm{a}$ & $24.24 \pm 8.80 b$ \\
\hline & UFR-6 & $0.00 \pm 0.00 \mathrm{~b}$ & $9.07 \pm 3.57 \mathrm{~b}$ & $3.68 \pm 2.21 \mathrm{~b}$ & $4.00 \pm 2.89 \mathrm{~b}$ & $12.34 \pm 5.56 \mathrm{bc}$ & $53.54 \pm 3.74 \mathrm{a}$ \\
\hline & B11R5T60 & $20.83 \pm 5.83 \mathrm{a}$ & $18.91 \pm 5.52 b$ & $31.40 \pm 4.79 \mathrm{a}$ & $19.21 \pm 4.60 \mathrm{a}$ & $23.73 \pm 5.08 \mathrm{ab}$ & $36.21 \pm 5.79 \mathrm{ab}$ \\
\hline & $2247 \times 6070-02-2$ & $28.01 \pm 4.44 \mathrm{a}$ & $9.10 \pm 2.54 \mathrm{~b}$ & $4.40 \pm 2.99 \mathrm{~b}$ & $5.83 \pm 2.65 b$ & $2.78 \pm 1.82 c$ & $6.21 \pm 4.67 c$ \\
\hline \multirow{4}{*}{ Drought } & Carrizo citrange & $54.15 \pm 7.62 b$ & $63.98 \pm 3.61 \mathrm{a}$ & $65.35 \pm 3.72 \mathrm{~ns}$ & $9.69 \pm 6.28 b$ & $35.04 \pm 6.04 \mathrm{a}$ & $33.33 \pm 6.06 \mathrm{ab}$ \\
\hline & UFR-6 & $58.47 \pm 7.45 \mathrm{ab}$ & $59.80 \pm 6.10 \mathrm{ab}$ & $63.24 \pm 6.09 \mathrm{~ns}$ & $6.38 \pm 2.84 b$ & $23.86 \pm 6.21 \mathrm{ab}$ & $65.15 \pm 2.53 \mathrm{a}$ \\
\hline & B11R5T60 & $45.39 \pm 7.65 b$ & $50.64 \pm 4.43 \mathrm{~b}$ & $59.88 \pm 5.83 \mathrm{~ns}$ & $9.15 \pm 5.27 b$ & $30.51 \pm 6.99 \mathrm{ab}$ & $42.41 \pm 4.41 \mathrm{~b}$ \\
\hline & $2247 \times 6070-02-2$ & $77.42 \pm 2.60 \mathrm{a}$ & $61.97 \pm 3.72 \mathrm{ab}$ & $72.71 \pm 2.25 \mathrm{~ns}$ & $35.00 \pm 4.67 \mathrm{a}$ & $16.67 \pm 5.94 b$ & $27.88 \pm 4.53 c$ \\
\hline \multirow{4}{*}{ Flooding } & Carrizo citrange & $52.68 \pm 6.41 b c$ & $40.99 \pm 5.18 \mathrm{a}$ & $44.55 \pm 6.17 \mathrm{ab}$ & $55.10 \pm 5.12 \mathrm{ab}$ & $30.12 \pm 5.55 a$ & $34.85 \pm 6.85 b$ \\
\hline & UFR-6 & $39.11 \pm 5.99 c$ & $19.12 \pm 7.58 \mathrm{~b}$ & $31.25 \pm 4.19 \mathrm{~b}$ & $53.15 \pm 8.79 a b$ & $11.53 \pm 6.95 b$ & $67.17 \pm 1.78 \mathrm{a}$ \\
\hline & B11R5T60 & $61.70 \pm 5.85 \mathrm{ab}$ & $46.15 \pm 3.75 \mathrm{a}$ & $54.94 \pm 8.37 \mathrm{a}$ & $51.22 \pm 7.37 \mathrm{~b}$ & $20.34 \pm 4.00 \mathrm{ab}$ & $35.78 \pm 7.63 \mathrm{~b}$ \\
\hline & $2247 \times 6070-02-2$ & $70.97 \pm 3.11 \mathrm{a}$ & $41.31 \pm 5.36 \mathrm{a}$ & $30.77 \pm 4.07 \mathrm{~b}$ & $70.00 \pm 3.09 \mathrm{a}$ & $29.17 \pm 7.25 b$ & $19.85 \pm 5.78 b$ \\
\hline
\end{tabular}

Values with different letters denote statistical differences among the rootstocks per treatment and plant section by Fisher's LSD test $(p<0.05)$. MWS: Medium Water Stress; ns: not significant.

\subsection{Plant Water Status}

\subsubsection{Leaf Water Potential}

All citrus rootstocks showed the lowest LWP value under the Drought treatment, with statistical differences compared with the water treatments for each rootstock assayed. Carrizo citrange showed similar LWP values in the Control, MWS and Flooding treatments, without significant differences among them. UFR- 6 did not show significant differences between MWS and Flooding, but these two treatments showed statistical differences with the Control treatment, which yielded the lowest value for this rootstock. For B11R5T60, the MWS, Flooding, and Control treatments showed a similar response among them without statistical differences. Lastly, the MWS treatment displayed significant differences compared with the control treatment in 2247 x 6070-02-2, although the Flooding treatment did not show statistical differences with MWS and Control (Figure 4).

\subsubsection{Stomatal Conductance}

Each rootstock showed a different response of stomatal conductance among the treatments assayed. Thus, the lowest and highest values of stomatal conductance were achieved with the Drought and Control treatments, respectively, with statistical differences when comparing both treatments for each citrus rootstock. In Carrizo citrange, the Flooding treatment showed a similar response to the Drought treatment without statistical differences, but they were statistically different compared with the Control response. MWS and Flooding did not show significant differences compared with the lowest rate of stomatal conductance; both these treatments displayed significant differences compared with the Control treatment in UFR-6. For B11R5T60, the MWS and Flooding treatments showed a similar response without statistical differences compared with the Control treatment. For 2247 x 6070-02-2, the MWS and Flooding treatments showed statistical differences compared with the highest and the lowest stomatal conductance rate (Figure 5). 


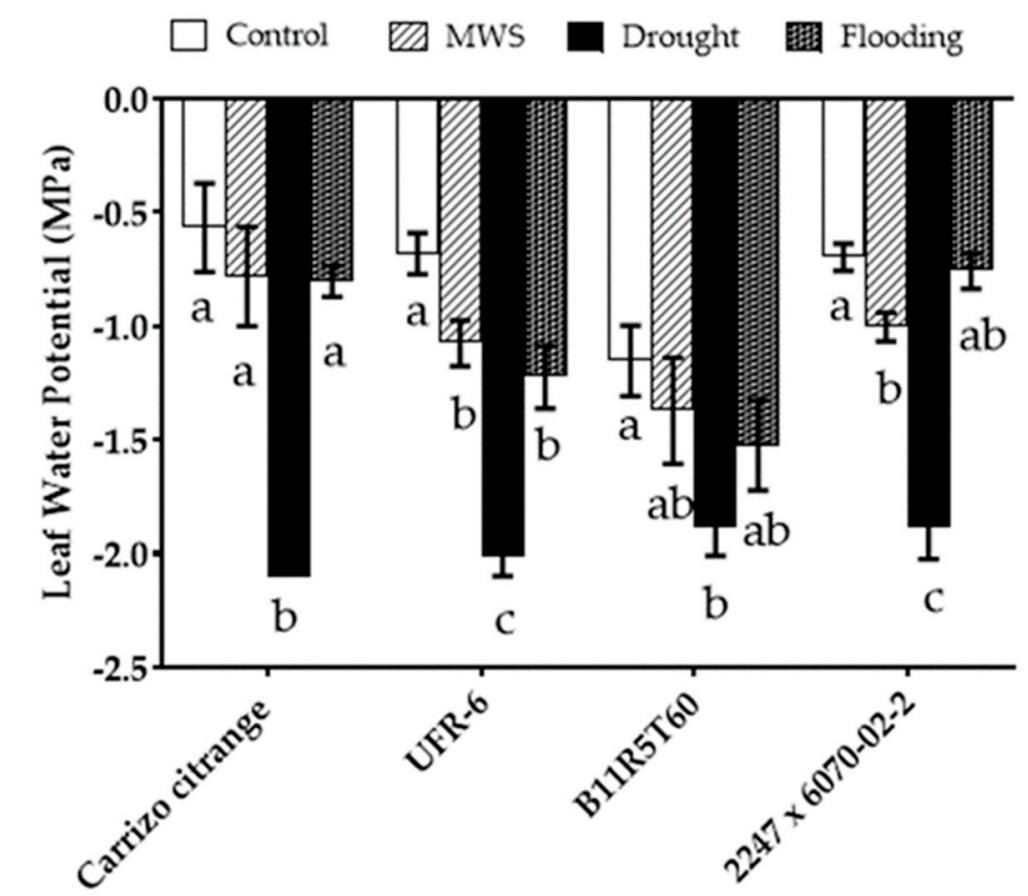

Citrus rootstocks

Figure 4. Leaf water potential (LWP; $\mathrm{MPa}$ ) at the end of the trial with the four citrus rootstocks studied (Carrizo citrange, UFR-6, B11R5T60, and $2247 \times 6070-02-2$ ) and under the four water treatments (Control, MWS, Drought, and Flooding). Values in columns with different letters denote statistical differences among the treatments for each rootstock by Fisher's LSD test $(p<0.05)$. MWS: Medium Water Stress.

Control MWS Drought 淍 Flooding

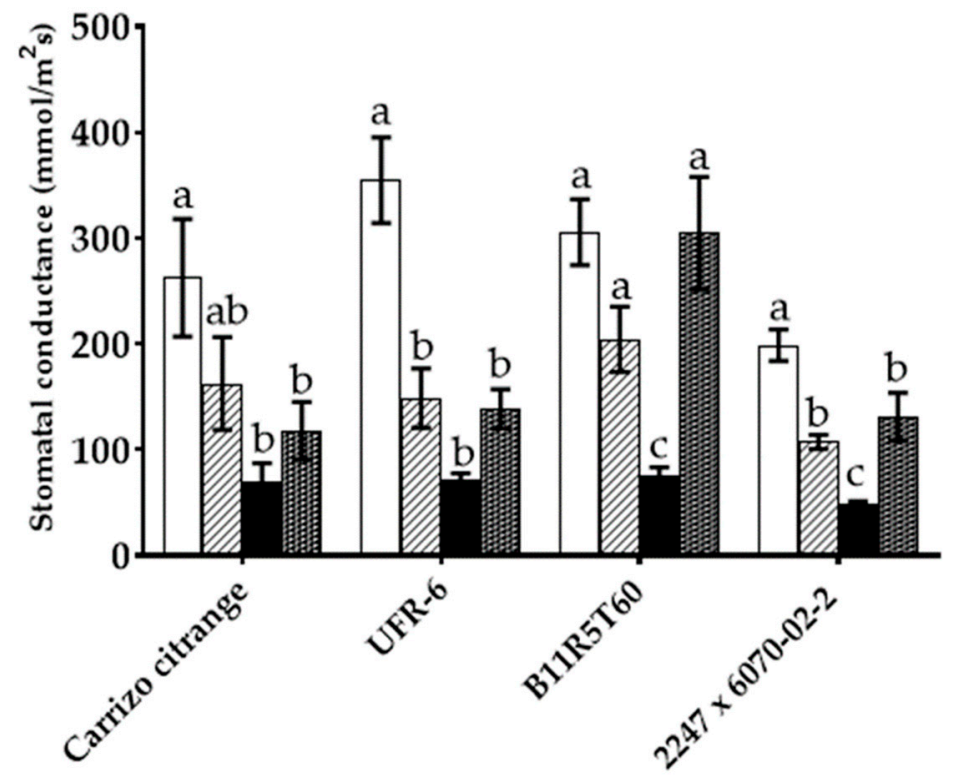

Citrus rootstocks

Figure 5. Mean stomatal conductance $\left(\mathrm{mmol} / \mathrm{m}^{2} \mathrm{~s}\right)$ at the end of the experiment with four water treatments (Control, MWS, Drought, and Flooding) using four citrus rootstocks (Carrizo citrange, UFR-6, B11R5T60, and $2247 \times 6070-02-2)$. Values in columns with different letters denote statistical differences among the treatments for each rootstock by Fisher's LSD test $(p<0.05)$. MWS: Medium Water Stress. 


\subsubsection{Relative Water Content}

At day 30 (D30), RWC was different among the water treatments per citrus rootstock; the lowest significant value of relative water content was found in the Flooding treatment for all citrus rootstocks assayed. Carrizo citrange and UFR-6 showed the highest relative water content rates compared with the Control and MWS treatments, without significant differences between them per rootstock, and with a significant reduction in the Drought treatment. In the cases of B11R5T60 and $2247 \times 6070-02-2$, the Control treatment displayed the highest significant value compared with the other water treatments (Figure 6).

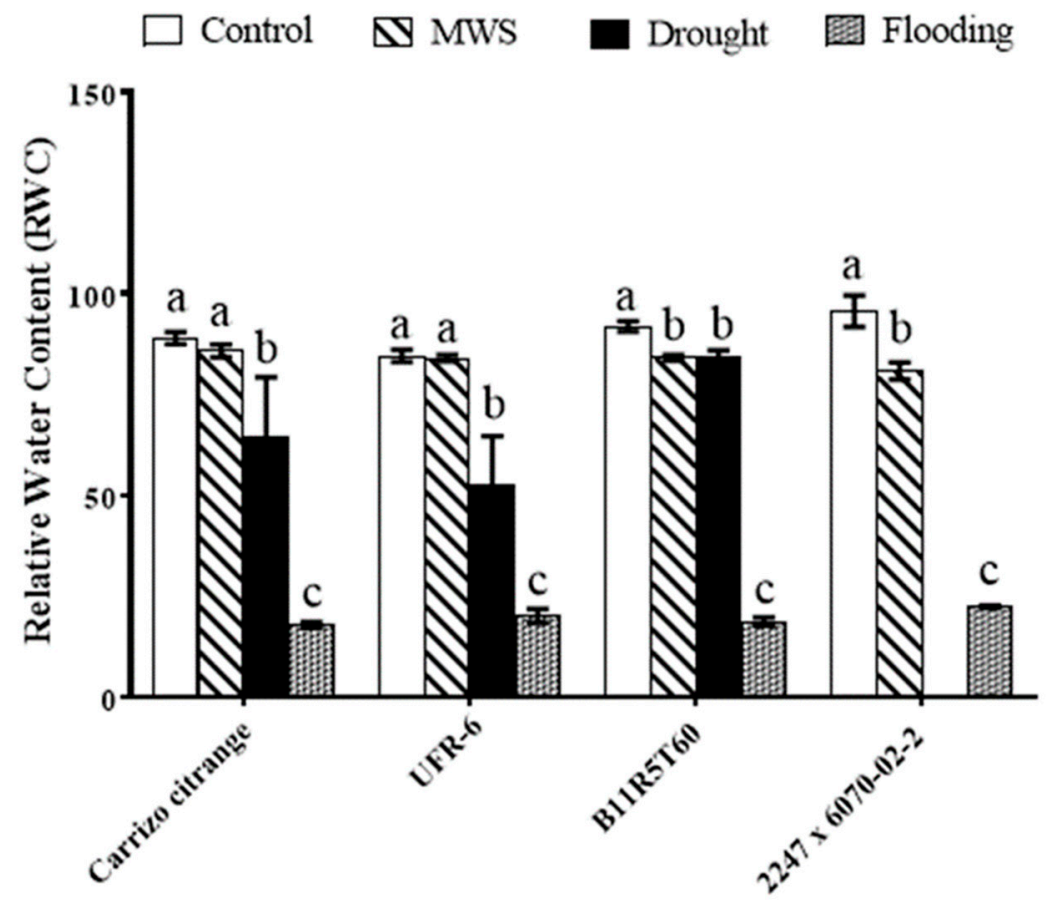

Citrus rootstocks

Figure 6. Relative water content (RWC) at day 30 of the assay in the four citrus rootstocks studied (Carrizo citrange, UFR-6, B11R5T60, and 2247 x 6070-02-2) and under four water treatments (Control, MWS, Drought, and Flooding). Values in columns with different letters denote statistical differences among treatments for each rootstock by Fisher's LSD test $(p<0.05)$. Note: data were not available for the Drought treatment of 2247 x 6070-02-2. MWS: Medium Water Stress.

\subsubsection{Electrolyte Leakage}

At the end of the assay (D30), EL in Carrizo citrange displayed nonsignificant differences among the water treatments (MWS: 4.69\% and Flooding: 2.85\%). However, UFR-6 showed the highest and the lowest EL value with the Drought (11.70\%) and MWS (2.41\%) treatments, respectively, with significant differences between them. For B11R5T60, no statistical differences were found among MWS $(0.24 \%)$, Drought $(0.11 \%)$, and Flooding $(3.58 \%)$ treatments. Finally, the highest and lowest EL values were found for the Flooding $(7.72 \%)$ and MWS (1.55\%) treatments, respectively, in 2247 x 6070-02-2, with statistical differences between them (Figure 7). 


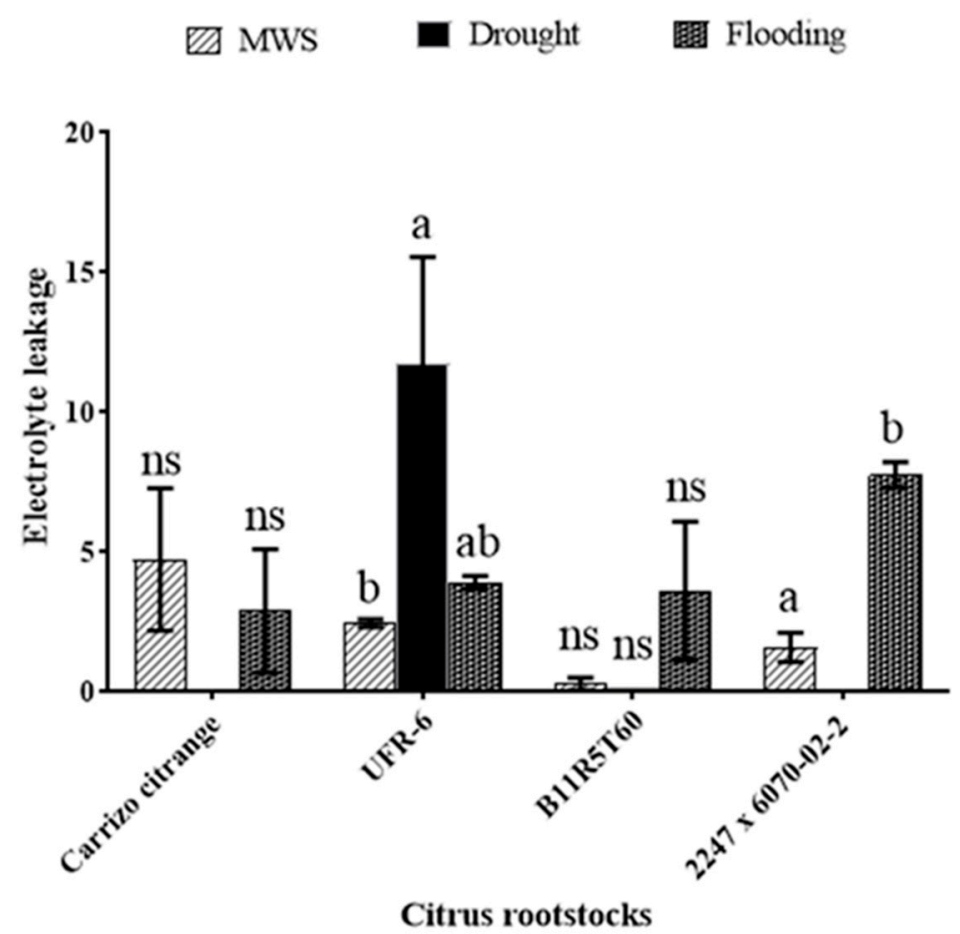

Figure 7. Electrolyte leakage (EL) at day 30 of the assay with the four citrus rootstocks studied (Carrizo citrange, UFR-6, B11R5T60, and $2247 \times$ 6070-02-2) and under four water stress (Control, MWS, Drought, and Flooding). Values in columns with different letters denote statistical differences among treatments for each rootstock by Fisher's LSD test $(p<0.05)$. Note: data were not available for the Drought treatment of Carrizo citrange, B11R5T60, and 2247 x 6070-02-2. MWS: Medium Water Stress; ns: not significant.

\section{Discussion}

Water stress is increasing in arable soils, which suffer from desertification and flooding due to climate change depending on the season and/or region. For this reason, selecting new citrus rootstocks that are more tolerant of various kinds of water stress is essential for future success in growing citrus crops. Appropriate rootstock selection helps to diminish the negative impact of drought and flooding in different crops [43-45]. In this study, we have successfully evaluated the effect of three water-stress conditions (plus control). Similarly, different authors have studied citrus rootstocks under different water conditions, such as flooding or drought, reporting different behavior among different plant materials $[45,46]$. However, few studies analyzed the effect of drought and flooding simultaneously [23]. In addition, this study provides information to help choose the most suitable citrus rootstock for propagation. At the end of the experiment, Carrizo citrange showed a reduction in the chlorophyll index under the Flooding conditions. This occurrence is common in citrus when these crops are affected by long periods of exposure to flooding conditions [47]. The chlorophyll index values did not decrease in all citrus rootstocks. As previous studies reported, loss of chlorophyll under flooding conditions depended on genotype [48]. The reduction of chlorophyll could be explained in some cases by the lack of absorption of micronutrients such as iron and manganese [47,49]. Thus, data related to chlorophyll is useful for determining long-term tolerance against flooding conditions; thus, our results demonstrated that B11R5T60, UFR-6, and 2247 × 6070-02-2 were more flood-tolerant than Carrizo citrange.

According to Romero et al. [50], water restrictions generate plant growth reduction in different citrus rootstocks species. Furthermore, others reported that flooding conditions generated a clear reduction of growth in height in all citrus rootstocks studied [14]. Our results showed a slight influence of water-stress conditions, depending on the water 
treatment and genotype. Thus, plant growth was higher in the Control than in the Flooding treatment for all citrus rootstocks at the end of the experiment.

On the other hand, biomass reduction can occur under drought conditions, though there may be no variation of biomass production in roots [16,51]. Our results suggested that Carrizo citrange is one of the rootstocks with the highest biomass reduction. According to other authors [52], biomass production stops early under water restrictions, and our study supported this conclusion, since all citrus rootstocks exhibited reduced biomass in stems and leaves under the MWS and Drought treatments. According to Lei et al. [53], physiological parameters, such as growth and/or biomass, are related to tolerance to water stress. In this study, the reduction in biomass was in line with the reduction in growth parameters.

As with other parameters described, LWP under water stress also depended on genotype [54]. This parameter is related to stomatal conductance; water potential alterations in stressed plants were reported to be a mechanism to maintain open stomata [55]. Water restrictions (Drought and MWS) caused a LWP reduction in these four citrus rootstocks; it was more pronounced in Carrizo citrange and UFR-6 under Drought stress, and in UFR-6 and 2247 x 6070-02-2 under MWS. Flooding conditions negatively affected LWP, and this was more accentuated in UFR-6 and B11R5T60.

Stomatal closure is a common response under water stress; usually it is the first response. The highest rate of stomatal closure in all four citrus rootstocks was under the Drought treatment. Stomatal closure is hormonally induced by abscisic acid (ABA) [56]; $\mathrm{ABA}$ is produced under drought stress for roots and leaves in citrus, and it is a trigger for mechanisms to avoid water loss $[20,57,58]$. Under the Flooding treatment, stomatal conductance in B11R5T60 was little changed, whereas Carrizo citrange, UFR-6, and $2247 \times 6070-02-2$ had lower stomatal conductance, reaching values similar to those under the Drought conditions. Stomatal closure under flooding conditions can occur due to ABA signal induction for roots and shoots [59]. In contrast, previous studies have reported increasing stomatal conductance in Carrizo citrange under short-term flooding conditions [23]; however, our results after 30 days of the Flooding treatment showed a reduction in stomatal conductance.

Previous studies reported that RWC and EL in crops were parameters to determine plant water status under different stress conditions [60-62]. RWC could be used to determine cell water status indirectly, and it was reduced in all stressed citrus rootstocks in our assay. However, our study showed the highest RWC reduction in the Flooding conditions; additionally, with water-restriction treatments, this parameter was reduced [23,54]. EL provides information about cell membrane stability and solute accumulations in cells, which is an avoidance strategy. EL increases under stress conditions, especially in sensitive rootstocks, and indicates that under stress conditions, cell membrane integrity is negatively affected [61,62]. Thus, our study showed the highest EL values were achieved under the Drought treatment for UFR-6 and Flooding for 2247 x 6070-02-2.

\section{Conclusions}

Our study provides useful information about the response of three promising new citrus rootstocks under water stress. These results can be helpful to Mediterranean and Floridian citrus growers when selecting the appropriate citrus rootstock to avoid waterstress problems in their orchards. Thus, the optimal choice against the Drought and Flooding treatments was obtained by B11R5T60, having for all water treatments a similar behavior as its control in most of the parameters studied, and an improved Carrizo citrange response. UFR-6 had increased SPAD values in all water conditions, and its highest value of growth and EL was achieved in the MWS and Drought treatments, respectively; furthermore, this candidate showed the lowest biomass rates with more frequency. UFR- 6 could be an accurate, promising choice due to its similar behavior to Carrizo citrange against water stress and its additional HLB tolerance. However, our results showed that 2247 x 6070-02-2 presented adequate behavior under MWS conditions for SPAD, growth in height, RGR, and 
PBR; additionally, the LWP was similar to the Control under Flooding conditions, as this citrus rootstock is not optimal for water-stress environments. Further research will evaluate water stress responses of these rootstocks in greenhouse and field conditions when grafted with the most common local scion cultivars.

Author Contributions: Conceptualization, F.J.A.-A.; methodology, L.A.-D., R.C.-V. and F.J.A.-A.; software, L.A.-D.; validation, F.J.A.-A., F.G.G.J. and Á.H.; formal analysis, L.A.-D. and R.C.-V.; investigation, L.A.-D., J.M.A.-L. and F.J.A.-A.; resources, F.J.A.-A.; data curation, J.M.A.-L., L.A.-D. and R.C.-V.; writing-original draft preparation, L.A.-D. and J.M.A.-L.; writing-review and editing, L.A.-D., F.J.A.-A., Á.H., J.M.A.-L. and F.G.G.J.; supervision, F.J.A.-A.; project administration, F.J.A.-A. All authors have read and agreed to the published version of the manuscript.

Funding: This research was funded by the research contract CEM 38/2018 Agromillora Catalana and the project "Network of Experimentation and Transfer, and the research in Andalusian Citrus (PR.TRA.TRA2019.001.001)", which was cofinanced (80\%) by the European Regional Development Fund within the FEDER Operational Program of Andalusia 2014-2020.

Institutional Review Board Statement: Not applicable.

Informed Consent Statement: Not applicable.

Acknowledgments: We are highly thankful to Agromillora Group for providing the plant material. The authors also are grateful to FPI-INIA for the 2016 grant (CPD2016-0130).

Conflicts of Interest: The authors declare no conflict of interest.

\section{References}

1. FAOSTAT. 2021. Available online: http://www.fao.org/faostat/es/\#data/QC (accessed on 4 April 2021).

2. Ruiz, I.; Almagro, M.; del Mar Solà, M.; Sanz, M.J. Assessment of sustainable land management practices in Mediterranean rural regions. J. Environ. Manag. 2020, 276, 111293. [CrossRef]

3. Puigdefábregas, J.; Mendizabal, T. Perspectives on desertification: Western Mediterranean. J. Arid Environ. 1998, 39, $209-224$. [CrossRef]

4. Safriel, U.N. Status of Desertification in the Mediterranean Region. In Water Scarcity, Land Degradation and Desertification in the Mediterranean Region; Rubio, J.L., Safriel, U., Daussa, R., Blum, W.E.H., Pedrazzini, F., Eds.; NATO Science for Peace and Security Series C: Environmental Security; Springer: Dordrecht, The Netherlands, 2009; pp. 33-73.

5. Kijne, J.W. Abiotic stress and water scarcity: Identifying and resolving conflicts from plant level to global level. Field Crop. Res. 2006, 97, 3-18. [CrossRef]

6. Holzapfel, E.A.; Pannunzio, A.; Lorite, I.; de Oliveira, A.S.S.; Farkas, I. Design and management of irrigation systems. Chil. J. Agric. Res. 2009, 69, 17-25. [CrossRef]

7. EPA. What Climate Change Means for Florida. 2016. Available online: https://www.epa.gov/sites/default/files/2016-08/ documents / climate-change-fl.pdf (accessed on 9 September 2021).

8. Vincent, C.; Morillon, R.; Arbona, V.; Gómez-Cadenas, A. Citrus in Changing Environments; Elsevier Inc.: Amsterdam, The Netherlands, 2020; ISBN 9780128122174.

9. Sharif, P.; Seyedsalehi, M.; Paladino, O.; Van Damme, P.; Sillanpää, M.; Sharifi, A.A. Effect of drought and salinity stresses on morphological and physiological characteristics of canola. Int. J. Environ. Sci. Technol. 2018, 15, 1859-1866. [CrossRef]

10. Colmenero-Flores, J.M.; Arbona, V.; Morillon, R.; Gómez-Cadenas, A. Salinity and Water Deficit. In The Genus Citrus; Elsevier Inc.: Amsterdam, The Netherlands, 2020; ISBN 9780128121634.

11. Arbona, V.; Marco, A.J.; Iglesias, D.J.; López-Climent, M.F.; Talon, M.; Gómez-Cadenas, A. Carbohydrate depletion in roots and leaves of salt-stressed potted Citrus clementina L. Plant Growth Regul. 2005, 46, 153-160. [CrossRef]

12. De Magalhães Erismann, N.; Machado, E.C.; Tucci, M.L.S.A. Photosynthetic limitation by $\mathrm{CO}_{2}$ diffusion in drought stressed orange leaves on three rootstocks. Photosynth. Res. 2008, 96, 163-172. [CrossRef]

13. Arbona, V.; Iglesias, D.J.; Jacas, J.; Primo-Millo, E.; Talon, M.; Gómez-Cadenas, A. Plant and Soil (2005) 270: 73-82 Hydrogel substrate amendment alleviates drought effects on young citrus plants. Plant Soil 2005, 270, 73-82. [CrossRef]

14. Kozlowski, T.T. Responses of woody plants to flooding and salinity. Tree Physiol. 2012, 17, 490. [CrossRef]

15. Brakke, M.; Allen, L.H. Gas exchange of Citrus seedlings at different temperatures, vapor-pressure deficits, and soil water contents. J. Am. Soc. Hortic. Sci. 1995, 120, 497-504. [CrossRef]

16. Pedroso, F.K.J.V.; Prudente, D.A.; Carolina, A.; Bueno, R.; Machado, E.C.; Ribeiro, R.V. Drought tolerance in citrus trees is enhanced by rootstock-dependent changes in root growth and carbohydrate availability. Environ. Exp. Bot. 2014, 101, 26-35. [CrossRef]

17. Ford, H.W. Poorly drained citrus soils. In Proceedings of the 1st International Citrus Symposium, Oakland, CA, USA, 16-26 March 1968; Volume 3, pp. 71-76. 
18. Sullivan, M.; VanToai, T.; Fausey, N.; Beuerlein, J.; Parkinson, R.; Soboyejo, A. Evaluating on-farm flooding impacts on soybean. Crop Sci. 2001, 41, 93-100. [CrossRef]

19. Martínez-Alcántara, B.; Jover, S.; Quiñones, A.; Forner-Giner, M.Á.; Rodríguez-Gamir, J.; Legaz, F.; Primo-Millo, E.; Iglesias, D.J. Flooding affects uptake and distribution of carbon and nitrogen in citrus seedlings. J. Plant Physiol. 2012, 169, $1150-1157$. [CrossRef] [PubMed]

20. Arbona, V.; Gómez-Cadenas, A. Hormonal modulation of citrus responses to flooding. J. Plant Growth Regul. 2008, 27, 241-250. [CrossRef]

21. Yang, F.; Han, C.; Li, Z.; Guo, Y.; Chan, Z. Dissecting tissue- and species-specific responses of two Plantago species to waterlogging stress at physiological level. Environ. Exp. Bot. 2015, 109, 177-185. [CrossRef]

22. Pucciarello, C.; Voesenek, L.A.C.J.; Perata, P.; Rashmi, S. Plant responses to flooding. Plant Sci. 2014, 5, 1-2. [CrossRef] [PubMed]

23. García-Sánchez, F.; Syvertsen, J.P.; Gimeno, V.; Botía, P.; Perez-Perez, J.G. Responses to flooding and drought stress by two citrus rootstock seedlings with different water-use efficiency. Physiol. Plant. 2007, 130, 532-542. [CrossRef]

24. Reighard, G.L.; Parker, M.L.; Krewer, G.W.; Beckman, T.G.; Wood, B.W.; Smith, J.E.; Whiddon, J. Impact of hurricanes on peach and pecan orchards in the Southeastern United States. HortScience 2001, 36, 250-252. [CrossRef]

25. Yang, C.; Powell, C.A.; Duan, Y.; Shatters, R.G.; Lin, Y.; Zhang, M. Mitigating citrus huanglongbing via effective application of antimicrobial compounds and thermotherapy. Crop Prot. 2016, 84, 150-158. [CrossRef]

26. Bové, J.M.; Ayres, A.J. Etiology of three recent diseases of citrus in São Paulo State: Sudden death, variegated chlorosis and huanglongbing. IUBMB Life 2007, 59, 346-354. [CrossRef]

27. Jagoueix, S.; Bove, J.M.; Garnier, M. The phloem-limited bacterium of greening disease of citrus is a member of the $\alpha$ subdivision of the Proteobacteria. Int. J. Syst. Bacteriol. 1994, 44, 379-386. [CrossRef]

28. Ichinose, K.; Hoa, N.V.; Bang, D.V.; Tuan, D.H.; Dien, L.Q. Limited efficacy of guava interplanting on citrus greening disease: Effectiveness of protection against disease invasion breaks down after one year. Crop Prot. 2012, 34, 119-126. [CrossRef]

29. Gottwald, T.R. Current epidemiological understanding of Citrus Huanglongbing. Annu. Rev. Phytopathol. 2010, 48, 119-139. [CrossRef] [PubMed]

30. Siverio, F.; Marco-Noales, E.; Bertolini, E.; Teresani, G.R.; Peñalver, J.; Mansilla, P.; Aguín, O.; Pérez-Otero, R.; Abelleira, A.; Guerra-García, J.A.; et al. Survey of huanglongbing associated with "Candidatus Liberibacter" species in Spain: Analyses of citrus plants and Trioza erytreae. Phytopathol. Mediterr. 2017, 56, 98-110. [CrossRef]

31. Arenas-Arenas, F.J.; Duran-Vila, N.; Quinto, J.; Hervalejo, Á. Is the presence of Trioza erytreae, vector of huanglongbing disease, endangering the Mediterranean citrus industry? Survey of its population density and geographical spread over the last years. J. Plant Pathol. 2018, 100, 567-574. [CrossRef]

32. Arenas-Arenas, F.J.; Duran-Vila, N.; Quinto, J.; Hervalejo, Á. Geographic spread and inter-annual evolution of populations of Trioza erytreae in the Iberian Peninsula. J. Plant Pathol. 2019, 101, 1151-1157. [CrossRef]

33. Tallón Vila, C.I. Biotechnology Applied to the Genetic Improvement of Citrus Rootstocks. Development of a Protocol for Micropropagation and Adventitious Regeneration for Use in Generating Salt Toleran Mutant Lines. Ph.D. Thesis, Universidad de Murcia, Murcia, Spain, 2015; p. 105.

34. Yelenosky, G.; Vu, J.C.V.; Wutscher, H.K. Influence of paclobutrazol in the soil on growth, nutrient elements in the leaves, and flood/freeze tolerance of citrus rootstock seedlings. J. Plant Growth Regul. 1995, 14, 129-134. [CrossRef]

35. Castle, W.S.; Bowman, K.D.; Grosser, J.W.; Futch, S.H.; Graham, J.H. Florida citrus rootstock selection guide. Univ. Fla. Coop. Ext. Publ. 2016, SP248. Available online: https://edis.ifas.ufl.edu/pdf\%5CHS\%5CHS126000.pdf (accessed on 9 September 2021).

36. Hussain, S.; Khalid, M.F.; Saqib, M.; Ahmad, S.; Zafar, W.; Rao, M.J.; Morillon, R.; Anjum, M.A. Drought tolerance in citrus rootstocks is associated with better antioxidant defense mechanism. Acta Physiol. Plant. 2018, 40, 1-10. [CrossRef]

37. Florida Citrus Rootstock Selection Guide, 4th ed.; University of Florida: Gainesville, FL, USA, 2021. Available online: https: / / crec.ifas.ufl.edu/extension/citrus_rootstock/tables.html (accessed on 30 August 2021).

38. Poorter, H. Interspecific variation in relative growth rate: On ecological causes and physiological consequences. In Causes and Consequences of Variation in Growth Rate and Productivity of Higher Plants; SPB Academic Publishing: Hague, The Netherlands, 1989; pp. $45-68$.

39. Vincent, J.M. Distortion of fungal hyphæ in the presence of certain inhibitors. Nature 1947, 159, 850. [CrossRef]

40. Scholander, P.F.; Bradstreet, E.D.; Hemmingsen, E.A.; Hammel, H.T. Sap Pressure in Vascular Plants. Science 1965, 148, 339-346. [CrossRef] [PubMed]

41. Rewald, B.; Raveh, E.; Gendler, T.; Ephrath, J.E.; Rachmilevitch, S. Phenotypic plasticity and water flux rates of Citrus root orders under salinity. J. Exp. Bot. 2012, 63, 2717-2727. [CrossRef] [PubMed]

42. Morgan, J.M. Osmoregulation and water stress in higher plants. Annu. Rev. plant Physiol. 1984, 35, 299-319. [CrossRef]

43. Bowman, K.D.; Joubert, J. Citrus rootstocks. In The Genus Citrus; Elsevier Inc.: Amsterdam, The Netherlands, 2020; ISBN 9780128121634.

44. Nakashima, K.; Yamaguchi-Shinozaki, K. ABA signaling in stress-response and seed development. Plant Cell Rep. 2013, 32, 959-970. [CrossRef]

45. Zaher-Ara, T.; Boroomand, N.; Sadat-Hosseini, M. Physiological and morphological response to drought stressin seedlings of ten citrus. Trees 2016, 30, 985-993. [CrossRef] 
46. Rodríguez-Gamir, J.; Ancillo, G.; González-Mas, M.C.; Primo-Millo, E.; Iglesias, D.J.; Forner-Giner, M.A. Root signalling and modulation of stomatal closure in flooded citrus seedlings. Plant Physiol. Biochem. 2011, 49, 636-645. [CrossRef]

47. Arbona, V.; López-Climent, M.F.; Pérez-Clemente, R.M.; Gómez-Cadenas, A. Maintenance of a high photosynthetic performance is linked to flooding tolerance in citrus. Environ. Exp. Bot. 2009, 66, 135-142. [CrossRef]

48. Partiya, R.; Ghazvini, R.F.; Fifaei, R.; Ghasemnezhad, M. Response of different citrus genotypes to continuous flooding conditions. Int. J. Hortic. Sci. Technol. 2018, 5, 253-263. [CrossRef]

49. Ponnamperuma, F.N. The Chemistry of Submerged Soils. Adv. Agron. 1972, 24, 29-96. [CrossRef]

50. Romero, P.; Navarro, J.M.; Pérez-Pérez, J.; García-Sánchez, F.; Gómez-Gómez, A.; Porras, I.; Martinez, V.; Botía, P. Deficit irrigation and rootstock: Their effects on water relations, vegetative development, yield, fruit quality and mineral nutrition of Clemenules mandarin. Tree Physiol. 2006, 26, 1537-1548. [CrossRef]

51. Santana-Vieira, D.D.S.; Freschi, L.; da Hora Almeida, L.A.; de Moraes, D.H.S.; Neves, D.M.; Dos Santos, L.M.; Bertolde, F.Z.; dos Santos Soares Filho, W.; Coelho Filho, M.A.; da Silva Gesteira, A. Survival strategies of citrus rootstocks subjected to drought. Sci. Rep. 2016, 6, 1-12. [CrossRef]

52. Zollinger, N.; Kjelgren, R.; Cerny-Koenig, T.; Kopp, K.; Koenig, R. Drought responses of six ornamental herbaceous perennials. Sci. Hortic. 2006, 109, 267-274. [CrossRef]

53. Lei, Y.; Yin, C.; Li, C. Differences in some morphological, physiological, and biochemical responses to drought stress in two contrasting populations of Populus przewalskii. Physiol. Plant. 2006, 127, 182-191. [CrossRef]

54. Rodríguez-Gamir, J.; Primo-Millo, E.; Forner, J.B.; Forner-Giner, M.A. Citrus rootstock responses to water stress. Sci. Hortic. 2010, 126, 95-102. [CrossRef]

55. García-Sánchez, F.; Syvertsen, J.P. Salinity tolerance of Cleopatra mandarin and Carrizo citrange citrus rootstock seedlings is affected by $\mathrm{CO}_{2}$ enrichment during growth. J. Am. Soc. Hortic. Sci. 2006, 131, 24-31. [CrossRef]

56. Nakashima, K.; Ito, Y.; Yamaguchi-Shinozaki, K. Update on abiotic stresses in arabidopsis and grasses transcriptional regulatory networks in response to abiotic stresses in arabidopsis and grasses 1. Plant Physiol. 2009, 149, 88-95. [CrossRef] [PubMed]

57. Davies, W.J.; Zhang, J. Root signals and the regulation of growth and development of plants in drying soil. Annu. Rev. Plant Physiol. Plant Mol. Biol. 1991, 42, 55-76. [CrossRef]

58. Chaves, M.M.; Flexas, J.; Pinheiro, C. Photosynthesis under drought and salt stress: Regulation mechanisms from whole plant to cell. Ann. Bot. 2009, 103, 551-560. [CrossRef] [PubMed]

59. Dat, J.F.; Capelli, N.; Folzer, H.; Bourgeade, P.; Badot, P.-M. Sensing and signalling during plant flooding. Plant Physiol. Biochem. 2004, 42, 273-282. [CrossRef]

60. Bielsa, B.; Hewitt, S.; Reyes-Chin-Wo, S.; Dhingra, A.; Rubio-Cabetas, M.J. Identification of water use efficiency related genes in "Garnem" almond-peach rootstock using time-course transcriptome analysis. PLoS ONE 2018, 13, 1-24. [CrossRef]

61. Bajji, M.; Kinet, J.M.; Lutts, S. The use of the electrolyte leakage method for assessing cell membrane stability as a water stress tolerance test in durum wheat. Plant Growth Regul. 2002, 36, 61-70. [CrossRef]

62. Verslues, P.E.; Agarwal, M.; Katiyar-Agarwal, S.; Zhu, J.; Zhu, J.K. Methods and concepts in quantifying resistance to drought, salt and freezing, abiotic stresses that affect plant water status. Plant J. 2006, 45, 523-539. [CrossRef] [PubMed] 